\title{
Analysis of projected changes in the occurrence of heat waves in Hungary
}

\author{
R. Pongrácz, J. Bartholy, and E. B. Bartha \\ Eötvös Loránd University, Budapest, Hungary \\ Correspondence to: R. Pongrácz (prita@nimbus.elte.hu) \\ Received: 7 February 2013 - Revised: 7 July 2013 - Accepted: 8 July 2013 - Published: 7 September 2013
}

\begin{abstract}
Heat wave events are important temperaturerelated hazards due to their impacts on human health. In 2004, a Heat Health Warning System including three levels of heat wave warning was developed on the basis of a retrospective analysis of mortality and meteorological data in Hungary to anticipate heat waves that may result in a large excess of mortality. Projected changes in the frequency of different heat wave warning levels are analysed for the 21st century. For this purpose, outputs of regional climate model PRECIS (Providing REgional Climates for Impacts Studies) are used taking into account three different global emissions scenarios (A2, A1B, B2). The results clearly show an increase in occurrence and length of heat waves with respect to the underlying emissions scenarios and regional climate model used. Moreover, the potential season of heat wave occurrences is projected to be lengthened by two months in 2071-2100 compared to 1961-1990.
\end{abstract}

\section{Introduction}

Human health is very likely affected by regional consequences of global warming. One of the most severe impacts is probably associated with temperature-related climatological extremes such as heat waves (Haines et al., 2006). Both General Circulation Models (GCM) and Regional Climate Models (RCM) project mean temperature increase for the coming decades (e.g., IPCC, 2007; Pongrácz et al., 2011). In this regard, hot conditions are likely to occur more frequently, longer, and more intensely than in the recent decades in most of the regions (Meehl and Tebaldi, 2004; IPCC, 2012). Infants, elderly people and individuals with health problems are especially vulnerable to extreme heat due to their lower capacities for adapting to unusual temperature ranges (e.g., Fritsch et al., 2008). In order to address this issue, societies and policy makers must develop appropriate adaptation and mitigation strategies both on national and local scales (Kovats and Ebi, 2006). For this purpose the very first step could be to analyse the projected future changes related to extreme temperature conditions. In this paper heat waves are addressed from this aspect. Clark et al. (2006) used GCM simulations to analyse extreme summer heat of the Northern Hemisphere, however, RCM outputs used here provide more precise regional details due to better spatial representations.

Several different definitions of heat wave exist and are used throughout the world (Koppe et al., 2004). In general, the applied approaches refer to a definite period of time during which the air temperature exceeds a certain threshold. This threshold varies geographically: different countries, different regions apply different threshold values (e.g., Robinson, 2001; Pascal et al., 2013). The World Meteorological Organization (WMO) recommends the following definition: a heat wave is considered to have occurred during the period when the daily maximum temperature exceeds the 1961-1990 daily maximum temperature normal (which is determined for each day separately) by $5^{\circ} \mathrm{C}$ for more than five consecutive days (Frich et al., 2002). This definition and other heat wave related indices are used in the analysis suggested and accomplished in the framework of the European Climate Assessment \& Dataset (ECA\&D) project (Klein Tank and Können, 2003), as well as the regional analysis completed for Central/Eastern Europe (Bartholy and Pongrácz, 2007). Gosling et al. (2009) collected and critically reviewed various definitions of characterizing heat waves. Analysis of Brown et al. (2008) focused on the observed extreme daily temperatures and their detected increases since 1950, whilst Moberg et al. (2006) analysed 
Table 1. Heat wave warning levels of HHWS applied in Hungary ( $T_{\text {mean }}$ indicates the daily mean temperature).

\begin{tabular}{lll}
\hline Levels & $\begin{array}{l}\text { Temperature } \\
\text { criteria }\end{array}$ & $\begin{array}{l}\text { Minimum length of } \\
\text { fulfilled temperature } \\
\text { criterium }\end{array}$ \\
\hline 1: Alert (Internal use) & $T_{\text {mean }}>25^{\circ} \mathrm{C}$ & 1 day \\
2: Preparedness (Public alert) & $T_{\text {mean }}>25^{\circ} \mathrm{C}$ & 3 days \\
3: Alarm (Strict control) & $T_{\text {mean }}>27^{\circ} \mathrm{C}$ & 3 days \\
\hline
\end{tabular}

detected trends of several extreme temperature and precipitation indices for the entire 20th century. Schär et al. (2004) compared the 2003 European heat wave to the projected climatic conditions.

Lowe et al. (2011) made a thorough internet-based search of policy documents on early warning systems with respect to heat waves in 33 European countries and identified such systems in 12 countries. The comparison concludes that despite many similarities among them (e.g., they involve meteorological institutions, they use similar indicators, they include similar actions, and they identify similar vulnerable groups), there are also some differences in key characteristics due to the unique climatic effects of particular regions, also, the available resources determine and may limit the possible actions taken or offered. Within the Central/Eastern European region, a Heat Health Warning System (HHWS) was developed in 2004 on the basis of a retrospective analysis of mortality and meteorological data (Páldy et al., 2005) in Hungary to anticipate heat waves that may result in a large excess of mortality. In the framework of this introduced HHWS, three levels of heat wave warning are applied. They are associated with the daily mean temperature values with different minimum length of heat wave, as presented in Table 1. The HHWS contains the following preventive actions and it is suggested that they should be taken within the country in case of issuance of the respective warning levels. Warning level 1: The emergency services should prepare for the expected increase in patient traffic. Warning level 2: (i) Use of media communications (TV, radio, internet), newsletters, flyers to inform the public, (ii) Operation of telephone emergency service, (iii) Distribution of water and fans in public places, (iv) Opening of air conditioned rooms for public use, (v) Suspension of the cut-off of non-paying clients by water and electricity suppliers. Warning level 3: Strict control of the Warning level 2 actions.

\section{Data and methodology}

For the present analysis simulated temperature outputs of PRECIS (Providing REgional Climates for Impacts Studies) experiments are used. The selection of this RCM is based on the validation results of a national intercomparison project (Krüzselyi et al., 2011). In the framework of this program four different RCMs have been adapted for assessing the re-

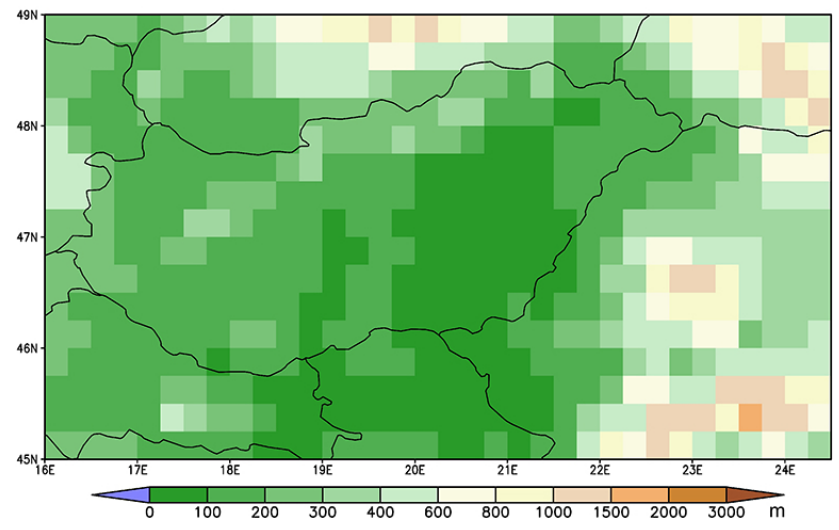

Fig. 1. Topography and grid cell representation of the selected domain covering Hungary.

gional climate change trends in the Carpathian Basin. Considering together the temperature and precipitation for the past, PRECIS outputs are able to reconstruct the climatic conditions in the 1961-1990 reference period.

PRECIS is a high resolution limited area model using a hydrostatic approach with 19 vertical atmospheric levels and 4 soil layers (Wilson et al., 2007). The depths of the applied soil layers were defined at $10 \mathrm{~cm}, 25 \mathrm{~cm}, 65 \mathrm{~cm}$, and $200 \mathrm{~cm}$ from the surface, which can result in realistic reproduction of the seasonal and diurnal variation of thermodynamical properties under the ground. The regional climate model was developed at the Hadley Climate Centre (HCC) of the UK Met Office, and it has been adapted for a European subdomain using $0.22^{\circ} \times 0.22^{\circ}$ horizontal resolution $(\sim 25 \mathrm{~km})$ covering the area between $35^{\circ} \mathrm{N}-55^{\circ} \mathrm{N}$ and $0^{\circ}-$ $32^{\circ} \mathrm{E}$ (Bartholy et al., 2009). The entire original integration area contains $123 \times 96$ grid cells, however, the selected region covering Hungary is represented by $34 \times 16$ grid cells shown in Fig. 1. PRECIS is based on the atmospheric module of the HadCM3 GCM; consequently, this finer scale version uses the same formulation of the climate system as in the global scale GCM. Therefore, the regional scale climate simulations are consistent with the continental scale conditions simulated by the GCM. The consistency is strengthened by the applied initial and lateral boundary conditions for the RCM experiments, which are provided by the HadCM3 ocean-atmosphere coupled GCM (Gordon et al., 2000) using $2.5^{\circ} \times 3.75^{\circ}$ latitude-longitude resolution. Three different emissions scenarios (B2, A1B, and A2) are taken into account in the PRECIS experiments. The global $\mathrm{CO}_{2}$ concentration level estimated for 2100 are $856 \mathrm{ppm}, 717 \mathrm{ppm}$, and $621 \mathrm{ppm}$, for A2, A1B and B2, respectively (Nakicenovic and Swart, 2000).

For the 1961-1990 reference period, performance of the HCC's model is compared to other RCMs in Jacob et al. (2007) and Kjellström et al. (2010) showing that the RCM developed by the HCC resulted in similar bias to other 
RCMs. In this study we used the standard reference period (1961-1990) of climate change research.

In order to estimate the bias of the PRECIS simulation for the past, raw outputs from the 1961-1990 reference period are compared to the E-OBS datasets (Haylock et al., 2008) containing gridded daily mean temperature values. The seasonal average temperature bias values for the Central/Eastern European domain are small in winter and autumn; for instance, the spatially averaged bias taking into account the grid cells located within Hungary is $0.2^{\circ} \mathrm{C}$ for both seasons. However, the mean temperature is underestimated in spring (the bias is $-1.4^{\circ} \mathrm{C}$ for Hungary) and significantly overestimated in summer, especially in July and August (the average seasonal bias is $+3.0^{\circ} \mathrm{C}$ for Hungary). Heat waves potentially occur in summer, therefore, a reliable analysis of heat wave warning levels requires the reduction of the large temperature bias of raw simulated data.

The bias of the raw PRECIS outputs is corrected using the monthly empirical frequency distribution (Formayer and Haas, 2010), which is determined from the daily mean temperature values for each month. Then, calculations of heat wave occurrence are accomplished from the corrected temperature data sets for each grid cell. For instance, in the grid cell close to Budapest, Hungary (geographical latitude and longitude of the RCM grid cell are $47^{\circ} 34^{\prime} \mathrm{N}$ and $19^{\circ} 2^{\prime} \mathrm{E}$, respectively), daily mean temperature values averaged over the month July during the 1961-1990 reference period, are overestimated by $3.1{ }^{\circ} \mathrm{C}$. The raw simulated temperature time series include daily mean temperature values exceeding $25^{\circ} \mathrm{C}$ with about $42 \%$ frequency during the 30 -year-long reference period (Fig. 2a), whereas according to the observation-based E-OBS dataset this occurrence is much more rare (about $11 \%$ frequency only). $10 \%$ of the raw simulated daily mean temperature values in this grid cell exceeded $30^{\circ} \mathrm{C}$ during 1961-1990, whereas this high temperature did not occur on the basis of the E-OBS control dataset. After applying the additive bias correction factor to the distribution of daily temperature values in July, the corrected simulation data perfectly fits the control measurements as shown both in case of the empirical distribution functions (Fig. 2a) and the empirical density functions (Fig. 2b).

\section{Analysis of future trends in heat wave occurrence frequency and schedule}

Heat wave occurrences (cases) are calculated from the bias corrected simulated temperature time series of PRECIS runs for three periods (1961-1990, 2021-2050, and 2071-2100) for the three warning levels of HHWS. Frequency values in the period 2071-2100 are determined for the three emissions scenarios, whereas in the period 2021-2050 only for the A1B scenario (due to the small differences in projected temperature for the different scenarios). Then, the projected changes by $2021-2050$ and by $2071-2100$ are determined relative to
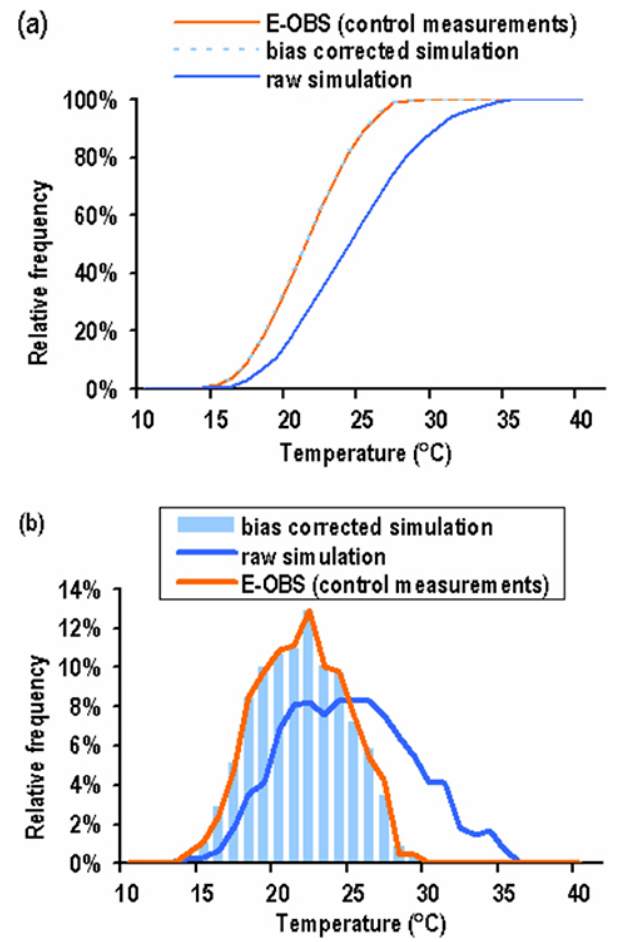

Fig. 2. Effect of bias correction on the distribution of daily mean temperature data for the grid cell representing Budapest (Hungary) in July, 1961-1990. Empirical distribution function (a) and empirical density function (b) of temperature time series.

the 1961-1990 reference period for each grid cell of the domain.

The spatial structures of the average annual number of heat warning cases based on simulated temperature with PRECIS, and thus, the projected changes for the target region are shown in Figs. 3 and 4 for warning levels 1 and 3, respectively. In general, zonal structure can be recognised in all levels, namely, from North to South the number of heat warning cases is increasing and the projected changes are also increasing. The topography of the selected domain remarkably modifies these general zonal structures. The topographical effect can be recognised as more heat wave warning cases occur in the lower elevated southern and central regions of the domain than in the higher elevated hilly regions in the northern and eastern parts of the domain. Furthermore, due to the increasing warming, simulated changes are larger for 2071-2100 than for 2021-2050. By the end of the 21st century, simulated changes are larger when taking into account a scenario with larger estimated $\mathrm{CO}_{2}$ concentration by 2100 resulting in larger temperature increase in the region (Pieczka et al., 2011). In the period 2071-2100, weather conditions with respect to heat wave warning levels 1 and 2 are projected to occur more frequently (in several subregions by $500-700 \%$ ) than in the 1961-1990 reference period. Simulated frequency increase of warning level 3 conditions is $230-370 \%$ on average. 


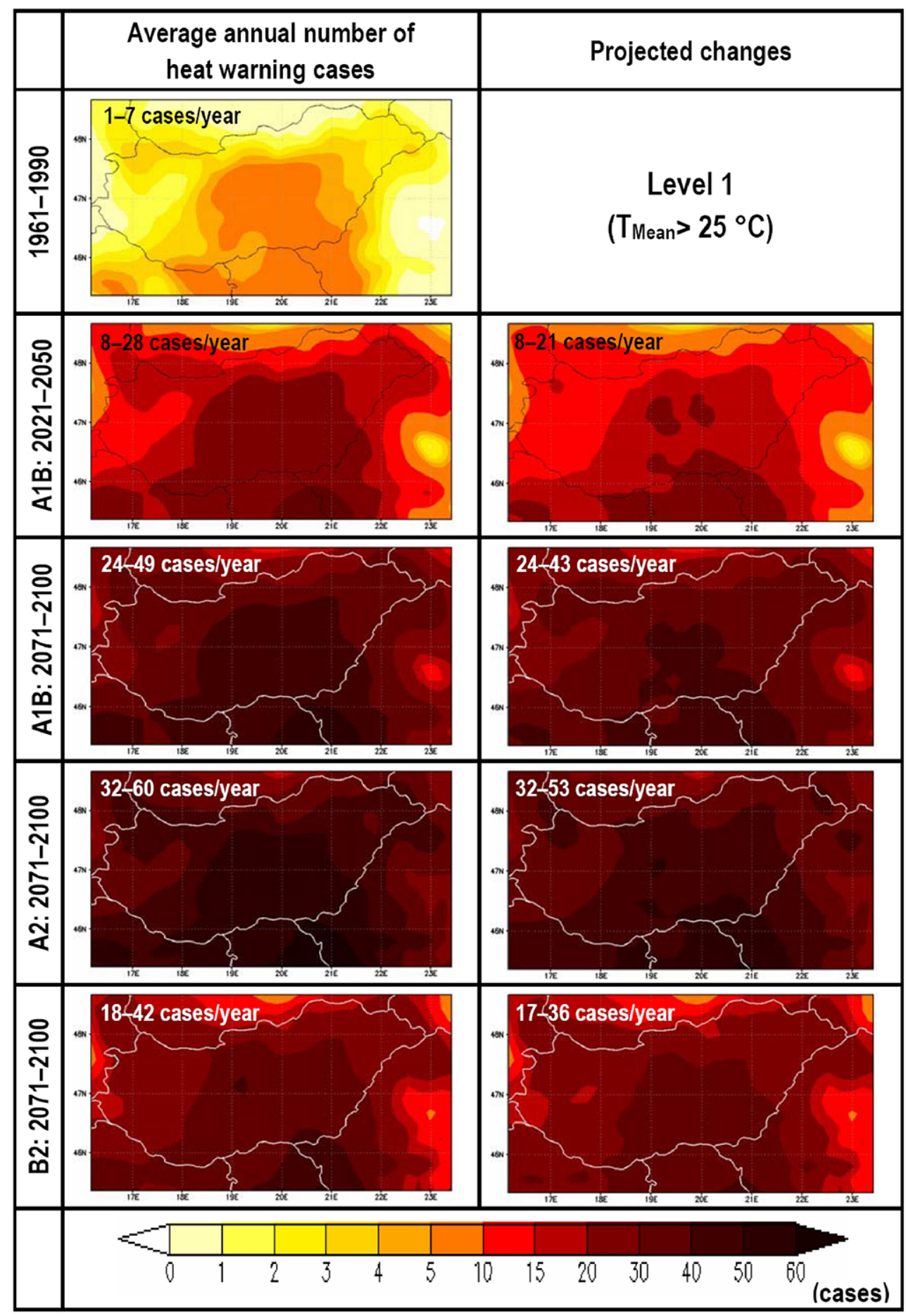

Fig. 3. Simulated occurrences of heat wave warning level 1 (left panel). Projected changes (right panel) are calculated relative to the 19611990 reference period.

The simulated average durations of warning level 2 and 3 conditions for Hungary are summarised in Table 2. Since the threshold values applied in case of warning levels 1 and 2 are identical, we do not calculate durations for warning level 1 separately. The standard deviation values indicate the vari- ability of the length of different warning level conditions. The remarkable intensity increase can be clearly identified both for the middle and the end of the 21 st century compared to the 1961-1990 reference period. For instance, level 2 heat waves lasted typically 4 days, which is projected to increase 


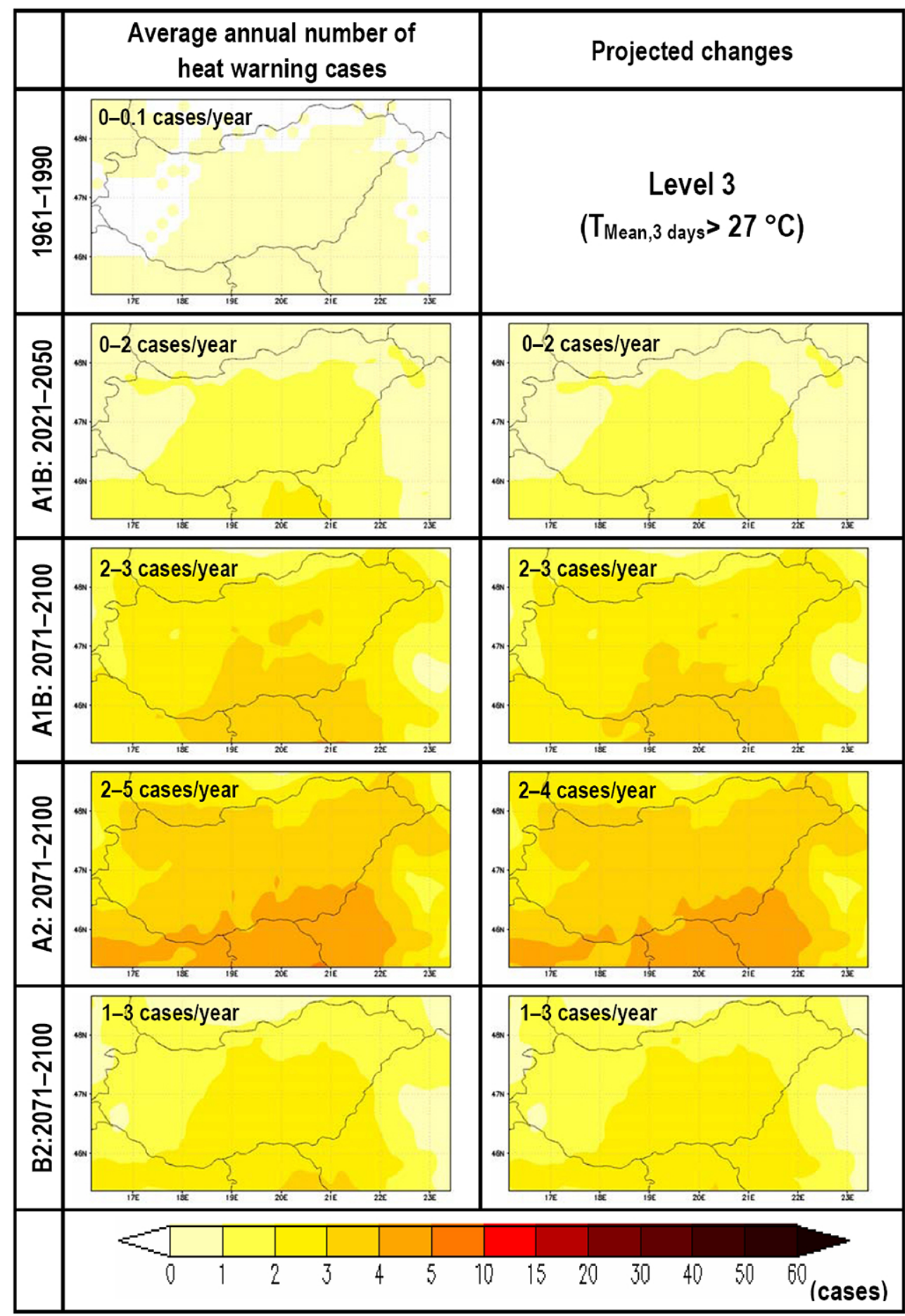

Fig. 4. Simulated occurrences of heat wave warning level 3 (left panel). Projected changes (right panel) are calculated relative to the 19611990 reference period.

by $50 \%$ by the mid-century, and to double by the end of the 21 st century in case of the A1B and the A2 scenario. The variability of the average length of heat waves is also projected to increase, which is partially due to the increased occurrences of heat waves in the future.
Besides the evaluation of the frequency in heat wave occurrence, the dates of the potential first and last warnings against heat waves with respect to different levels within HHWS have been analysed for Hungary. The Box-Whisker plots in Figs. 5 and 6 summarise the results for the 229 grid 
Table 2. Simulated lengths of heat waves corresponding to warning levels 2 and 3 within HHWS in Hungary.

\begin{tabular}{lll}
\hline Period/Scenario & $\begin{array}{l}\text { Level 2: Average length (days) } \\
\text { and standard deviation (days) }\end{array}$ & $\begin{array}{l}\text { Level 3: Average length (days) } \\
\text { and standard deviation (days) }\end{array}$ \\
\hline 1961-1990/CTL & $4(1.3)$ & $3(0.2)$ \\
$2021-2050 /$ A1B & $6(1.8)$ & $4(2.1)$ \\
2071-2100/B2 & $6(2.5)$ & $5(2.1)$ \\
2071-2100/A1B & $8(3.9)$ & $7(4.0)$ \\
2071-2100/A2 & $8(3.3)$ & $7(2.7)$ \\
\hline
\end{tabular}

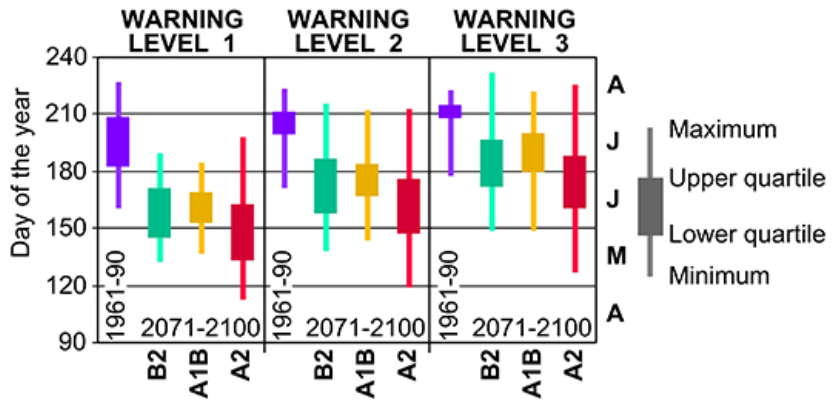

Fig. 5. Simulated first occurrences of heat wave warning levels for 1961-1990 and for 2071-2100 according to three different emissions scenarios. A, M, J, J, and A on the right indicate April, May, June, July, and August, respectively.

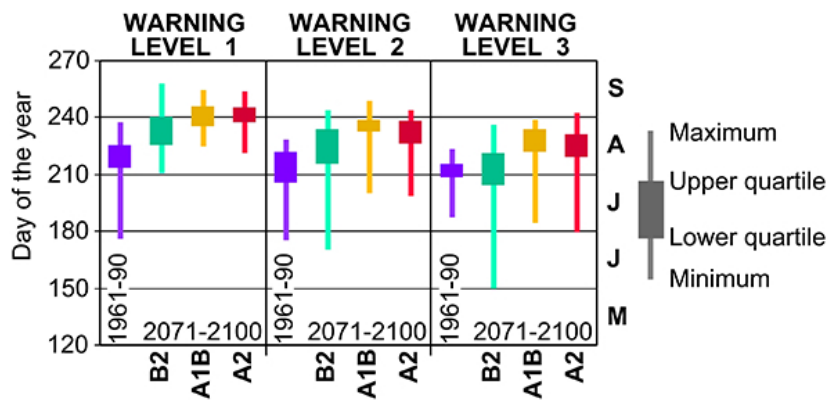

Fig. 6. Simulated last occurrences of heat wave warning levels for 1961-1990 and for 2071-2100 according to three different emissions scenarios. M, J, J, A, and S on the right indicate May, June, July, August, and September, respectively.

cells located within the country. In general, the results suggest that the interannual variability of the simulated time series is larger in the period 2071-2100 compared to 19611990. The average start of heat warnings is projected to shift to the months May and June compared to the month of July in the period 1961-1990 (Fig. 5). Meanwhile, the average end of heat warnings is likely to shift from early August to late August/beginning of September (Fig. 6). Thus the length of the potential heat wave season is projected to remarkably increase in Hungary.
Similarly to the mean annual number of heat waves, the spatial structure of the occurrence schedule can also be characterised by superposed zonal and topographical features. Heat waves tend to occur earlier and last longer in the lower elevated southern regions of the domain than in the higher elevated hilly regions.

In the 21 st century, the potential occurrence times of heat wave warnings are likely to be extended; namely, the first (last) heat wave occurrence within the year is projected to shift earlier (later) than during the 1961-1990 reference period. For instance, warning level 1 conditions might occur from mid-May until mid-September in the late 21st century, unlike in the reference period (when they occurred only from mid-June until mid-August). Thus, the total length of the possible occurrence is likely to be extended by about $1-2$ months.

\section{Conclusions}

Heat wave related climatic conditions of the 1961-1990 (reference), 2021-2050 and 2071-2100 (future) periods have been simulated using the PRECIS model outputs. In the present paper the projected changes of regional heat waves in Hungary (located in Central/Eastern Europe) for the 21st century (compared to 1961-1990) have been analysed in case of three different emissions scenarios (B2, A1B, and A2). Based on the results, the following main conclusions can be drawn.

i. Heat waves in the region are likely to occur significantly more often in the 21st century than in the 1961-1990 reference period. The larger the estimated $\mathrm{CO}_{2}$ level by 2100 , the larger the projected increase.

ii. The period of heat waves is projected to considerably lengthen. Typical duration is likely to double by the 2071-2100 period (especially in case of the A2 or A1B scenarios) compared to the 1961-1990 reference period.

iii. By the end of the 21st century the average first heat wave warning is projected to occur earlier, and the average last heat wave warning is projected to occur later than in the reference period - hence the potential heat wave season is projected to increase remarkably. 
Acknowledgements. This work was partially supported by the European Union and the European Social Fund through the project FuturICT.hu (grant no.: TÁMOP-4.2.2.C-11/1/KONV-2012-0013). Research leading to this paper has been supported by the Hungarian National Science Research Foundation under grant K-78125, and projects KMR_12-1-2012-0206, GOP-1.1.1.-11-2012-0164. We acknowledge the E-OBS dataset from the EU-FP6 project ENSEMBLES (http://ensembles-eu.metoffice.com), and the data providers in the ECA\&D project (http://eca.knmi.nl).

Edited by: K. Tokeshi

Reviewed by: I. Bogardi and F. Strauss

\section{References}

Bartholy, J. and Pongrácz, R.: Regional analysis of extreme temperature and precipitation indices for the Carpathian Basin from 1946 to 2001, Global Planet. Change, 57, 83-95, 2007.

Bartholy, J., Pongrácz, R., Pieczka, I., Kardos, P., and Hunyady, A.: Analysis of expected climate change in the Carpathian Basin using a dynamical climate model, Lect. Notes Comput. Sc., 5434, 176-183, 2009.

Brown, S. J., Caesar, J., and Ferro, C. A. T.: Global changes in extreme daily temperature since 1950, J. Geophys. Res., 113, D05115, doi:10.1029/2006JD008091, 2008.

Clark, R., Brown, S., and Murphy, J.: Modelling northern hemisphere summer heat extreme changes and their uncertainties using a physics ensemble of climate sensitivity experiments, J. Climate, 19, 4418-4435, 2006.

Formayer, H. and Haas, P.: Correction of RegCM3 model output data using a rank matching approach applied on various meteorological parameters, Deliverable D3.2 RCM output localization methods, http://www.cecilia-eu.org/ (last access: 1 February 2013), 2010.

Fritsch, N., Kreis, G., and Matthies, F.: Improving Public Health Responses to Extreme Weather/Heat-Waves - EuroHEAT, WHO Europe, Copenhagen, 2008.

Frich, P., Alexander, L. V., Della-Marta, P., Gleason, B., Haylock, M., Klein Tank, A. M. G., and Peterson, T.: Observed coherent changes in climatic extremes during 2 nd half of the 20th century, Clim. Res., 19, 193-212, 2002.

Gordon, C., Cooper, C., Senior, C. A., Banks, H., Gregory, J. M., Johns, T. C., Mitchell, J. F. B., and Wood, R. A.: The simulation of SST, sea ice extents and ocean heat transports in a version of the Hadley Centre coupled model without flux adjustments, Clim. Dynam., 16, 147-168, 2000.

Gosling, S. N., Lowe, J. A., McGregor, G. R., Pelling, M., and Malamud, B. D.: Associations between elevated atmospheric temperature and human mortality: a critical review of the literature, Climatic Change, 92, 299-341, 2009.

Haines, A., Kovats, S., Campbell-Lendrum, D., and Corvalan, C.: Climate change and human health: impacts, vulnerability, and mitigation, Lancet, 367, 2101-2109, 2006.

Haylock, M. R., Hofstra, N., Klein Tank, A. M. G., Klok, E. J., Jones, P. D., and New, M.: A European daily high-resolution gridded dataset of surface temperature and precipitation, J. Geophys. Res. (Atmos.), 113, D20119, doi:10.1029/2008JD010201, 2008.
IPCC: Climate Change 2007: The Physical Science Basis, Contribution of Working Group I to the Fourth Assessment Report of the Intergovernmental Panel on Climate Change, edited by: Solomon, S., Qin, D., Manning, M., Chen, Z., Marquis, M., Averyt, K. B., Tignor, M., and Miller, H. L., Cambridge University Press, Cambridge, UK and New York, NY, 2007.

IPCC: Managing the Risks of Extreme Events and Disasters to Advance Climate Change Adaptation, A Special Report of Working Groups I and II of the IPCC, edited by: Field, C. B., Barros, V., Stocker, T. F., Qin, D., Dokken, D. J., Ebi, K. L., Mastrandrea, M. D., Mach, K. J., Plattner, G.-K., Allen, S. K., Tignor, M., and Midgley, P. M., Cambridge University Press, Cambridge, UK and New York, NY, 2012.

Jacob, D., Bärring, L., Christensen, O. B., Christensen, J. H., de Castro, M., Déqué, M., Giorgi, F., Hagemann, S., Hirschi, M., Jones, R., Kjellström, E., Lenderink, G., Rockel, B., Sánchez, E., Schär, Ch., Seneviratne, S. I., Somot, S., van Ulden, A., and van den Hurk, B.: An inter-comparison of regional climate models for Europe: Model performance in Present-Day Climate, Climatic Change, 81, 21-53, 2007.

Kjellström, E., Boberg, F., Castro, M., Christensen, J. H., Nikulin, G., and Sánchez, E.: Daily and monthly temperature and precipitation statistics as performance indicators for regional climate models, Clim. Res., 44, 135-150, 2010.

Klein Tank, A. M. G. and Können, G. P.: Trends in Indices of Daily Temperature and Precipitation Extremes in Europe, 1946-99, J. Climate, 16, 3665-3680, 2003.

Koppe, C., Jendritzky, G., Kovats, R. S., and Menne, B.: Heatwaves: impacts and responses, WHO, Copenhagen, 2004.

Kovats, R. S. and Ebi, K. L.: Heatwaves and public health in Europe, Eur. J. Public Health, 16, 592-599, 2006.

Krüzselyi, I., Bartholy, J., Horányi, A., Pieczka, I., Pongrácz, R., Szabó, P., Szépszó, G., and Torma, Cs.: The future climate characteristics of the Carpathian Basin based on a regional climate model mini-ensemble, Adv. Sci. Res., 6, 69-73, doi:10.5194/asr6-69-2011, 2011.

Lowe, D., Ebi, K. L., and Forsberg, B.: Heatwave early warning systems and adaptation advice to reduce human health consequences of heatwaves, Int. J. Environ. Res. Public Health, 8, 4623-4648, doi:10.3390/ijerph8124623, 2011.

Meehl, G. A. and Tebaldi, C.: More intense, more frequent, and longer lasting heat waves in the 21st century, Science, 305, 994 997, 2004.

Moberg, A., Jones, P., Lister, D., Walther, A., Brunet, M., Jacobeit, J., Alexander, L., Della-Marta, P., Luterbacher, J., Yiou, P., Chen, D., Tank, A., Saladie, O., Sigro, J., Aguilar, E., Alexandersson, H., Almarza, C., Auer, I., Barriendos, M., Begert, M., Bergstrom, H., Bohm, R., Butler, C., Caesar, J., Drebs, A., Founda, D., Gerstengarbe, F., Micela, G., Maugeri, M., Osterle, H., Pandzic, K., Petrakis, M., Srnec, L., Tolasz, R., Tuomenvirta, H., Werner, P. Linderholm, H., Philipp, A., Wanner, H., and Xoplaki, E.: Indices for daily temperature and precipitation extremes in Europe analyzed for the period 1901-2000, J. Geophys. Res., 111, D22106, doi:10.1029/2006JD007103, 2006.

Nakicenovic, N. and Swart, R. (Eds.): Emissions Scenarios, A Special Reports of IPCC Working Group III, Cambridge University Press, Cambridge, UK, 2000.

Páldy, A., Bobvos, J., Vámos, A., Kovats, R. S., and Hajat, S.: The effect of temperature and heat waves on daily mortality in $\mathrm{Bu}-$ 
dapest, Hungary, 1970-2000, in: Extreme weather events and public health responses, edited by: Kirch, W., Menne, B., and Bertollini, R., WHO, Springer, 99-108, 2005.

Pascal, M., Wagner, V., Le Tertre, A., Laaidi, K., Honoré, C., Bénichou, F., and Beaudeau, P.: Definition of temperature thresholds: the example of the French heat wave warning system, Int. J. Biometeorol., 57, 21-29, 2013.

Pieczka, I., Pongrácz, R., and Bartholy, J.: Comparison of simulated trends of regional climate change in the Carpathian Basin for the 21 st century using three different emission scenarios, Acta Silvatica et Lignaria Hungarica, 7, 9-22, 2011.

Pongrácz, R., Bartholy, J., and Miklós, E.: Analysis of projected climate change for Hungary using ENSEMBLES simulations, Appl. Ecol. Env. Res., 9, 387-398, 2011.
Robinson, P. J.: On the definition of a heat wave, J. Appl. Meteorol., 40, 762-775, 2001.

Schär, C., Vidale, P.L., Lüthi, D., Frei, C., Häberli, C., Liniger, M. A., and Appenzeller, C.: The role of increasing temperature variability in European summer heatwaves, Nature, 427, 332-336, 2004.

Wilson, S., Hassell, D., Hein, D., Jones, R., and Taylor, R.: Installing and using the Hadley Centre regional climate modelling system, PRECIS, Version 1.5.1. UK Met Office Hadley Centre, Exeter, 2007. 